\title{
Using Landsat Data to Assess the Status of Coral Reefs Cover along the Red Sea Coast, Egypt
}

\author{
Mostafa Khaled ${ }^{1,2,3, ~ *}$, Frank Muller-Karger ${ }^{1}$, Ahmad Obuid-Allah $^{3}$, \\ Mahmoud Ahmed $^{2}$, Sameh El-Kafrawy ${ }^{2}$ \\ ${ }^{1}$ Institute for Marine Remote Sensing, College of Marine Science, University of South Florida, St. Petersburg, USA \\ ${ }^{2}$ Department of Marine Science, National Authority for Remote Sensing \& Space Science, Cairo, Egypt \\ ${ }^{3}$ Department of Zoology, Faculty of Science, Assiut University, Assiut, Egypt
}

Email address:

mostafaalmaghraby@yahoo.com (M. Khaled)

${ }^{*}$ Corresponding author

\section{To cite this article:}

Mostafa Khaled, Frank Muller-Karger, Ahmad Obuid-Allah, Mahmoud Ahmed, Sameh El-Kafrawy. Using Landsat Data to Assess the Status of Coral Reefs Cover along the Red Sea Coast, Egypt. International Journal of Ecotoxicology and Ecobiology.

Vol. 4, No. 1, 2019, pp. 17-31. doi: 10.11648/j.jjee.20190401.13

Received: December 29, 2018; Accepted: February 16, 2019; Published: March 14, 2019

\begin{abstract}
The Egyptian Red Sea coast has experienced rapid development since the 1970's. In particular, the coastal area near the City of Hurghada has been transformed into a long strip of touristic villages and hotels in this short time span. This is an area that has historically had abundant and diverse coral reef communities. To assess possible impacts on benthic coral reef cover in the region, Landsat satellite data collected over the Red Sea from 1973 through 2015 were analyzed to estimate urban expansion in the Hurghada region, shoreline changes, and changes in coral reef cover over time. A time series of satellite observations using Landsat 1-MSS, Landsat 5-TM, Landsat 7-ETM+, and Landsat 8-OLI was assembled, with images acquired in 1973, 1984, 1987, 1992, 1998, 2000, 2003, 2010, and 2015. Images were geometrically, radiometrically and atmospherically corrected, and a water-column correction was implemented prior to comparing images to assess change in landcover. The results show that during the last 42 years, the coral reef cover decreased $6.21 \mathrm{Km}^{2}$ while the built coastal area increased $13.4 \mathrm{Km}^{2}$. These observations were used to compute total economic value (TEV) of coral reef habitats and the cost of degradation in terms of physical losses of coral reef area which equals about $18.63 \$$ Billion.
\end{abstract}

Keywords: Remote Sensing, Landsat, Coral Reefs, Water Quality, Total Economic Value

\section{Introduction}

The Red Sea is the world's northernmost tropical sea [1]. It holds an extraordinary range of habitats and biological diversity and endemism, with over 1,000 invertebrate species including over 300 species of soft and hard corals and more than 1,200 species of fishes. Coral reefs, mangroves, and sea grass beds provide key food resources, shoreline protection, stabilization and other economic benefits [2]. The Egyptian coastline of the Red Sea features about 1,800 km long fringing reef areas, altogether covering about $3800 \mathrm{Km}^{2}$ [34]. Egyptian reefs host about 200 species of hard corals, including some endemic species [5]. These resources are facing increasing threats from coastal development to service a growing tourism industry [6-7].
A widely cited report on tourism and economic development warns that coral reefs along the Egyptian coast have been damaged as a result of coastal urban development [8]. In particular, the coastal area near the City of Hurghada has been transformed into a long $46 \mathrm{~km}$ strip of touristic villages and hotels. The number of hotel rooms at Hurghada increased from a few hundred in 1989 to 35,000 in 2004 [5]. The number of tourism boats in Hurghada has also increased, from less than 50 in 1989 to over 1200 in 2006 [9]. This has led to higher incidence disposal of construction materials and discharges into coastal areas, and direct interactions between divers and boats and marine organisms like coral reefs, including anchoring and boat groundings.

Hurghada was originally a small fishing village. In the 1980s, it became the first tourist resort on the Egyptian Red 
Sea, driven by tourism seeking pristine diving destinations [10]. The only other comparable destination in the region at the time was Eilat [11]. Around 600,000 dives per year take place in the Hurghada area alone [12]. This has led to direct physical damage from construction on harbours, airports, and tourist resorts, and by mining the reef areas for construction materials [13].

Satellite remote-sensing techniques have been widely used in detecting and monitoring land cover change at various scales (such as: [14-18]). Time series of remote sensing observations are helpful to observe and evaluate changes in urban environments and in land use as development [19-23]. When combined with geographical information systems (GIS) and studies using global positioning systems (GPS), remote sensing is a powerful tool to assess change in land and coastal substrates [24].

Change detection algorithms are used to identify areas of disturbance and to determine the areal extent and the spatial pattern of change [25]. Some change detection methods involve simple image overlays to visualize change while others use image differencing. A popular quantitative method uses sequences of thematically classified images for evaluating change over time [26].

The extent of coral cover in the Red Sea has not been well documented to date. Past studies have used qualitative density measures such as 'low', 'medium', and 'high' coral density to describe distribution [27-28]. In this paper, a quantitative assessments of coral reef habitat is provided for the Egyptian waters of the Red Sea near the popular tourist center of Hurghada, Egypt, for the 42 year period spanning 1973 to 2015.

The main goal of this paper is using remote sensing techniques to (1) assess the anthropogenic effects on shoreline and urban development changes at Hurghada City, (2) estimate the total economic value losses during the four past decades, (3) assess the status of coral reefs and associated fisheries along the Hurghada Coast as they are the key factors affecting sustainable development in Red Sea.

\section{Materials \& Methods}

\subsection{Study Area}

The urbanized area of Hurghada is divided into three main districts. These are El Dahar, Al - Sekalla, and Al Ahiaa. The study area extending from El Gouna Resort to Magawish Resort (Figure 1) covers approximately $46 \mathrm{~km}$ in length and $35 \mathrm{~km}$ in width.

\subsection{Remote Sensing Data}

Nine satellite images collected by the Landsat series of sensors were used to evaluate coral reef changes. These included images from the Landsat 1-MSS, Landsat 5-TM, and Landsat 8-OLI sensors collected in 1973, 1984, 1987, 1992, 1998, 2000, 2003, 2010 and 2015 (Table 1). Images were downloaded from the United States Geological Survey (USGS) (http://earthexplorer.usgs.gov/). Each of the Landsat sensors had slightly different spectral band combinations (Table 2). The images were registered geographically to match topographic maps of scale 1: 25.000 published by Egyptian Military Survey (2005). Water quality data collected from field surveys four times per year from 1998 to 2012 were obtained from the Egyptian Environmental Affairs Agency [29]. Fish abundance data from the General Authority for Fish Resources Development (GAFRD, 1991-2007) was obtained for the period 1991 to 2007.

All satellite images were georeferenced and geometrically corrected to match a WGS 84 datum (world geographic system), UTM (Universe Transverse Mercator) Projection with Zone 36 North. Ground control points were collected in the field using Guno Trimble GPS. Images were radio metrically and atmospherically corrected, and a water-column correction was applied [30]. Images were converted from digital number (DN) values to physical units $\left(\mathrm{W} \mathrm{m}^{-2} \mathrm{sr}^{-1} \mu \mathrm{m}^{-1}\right)$ using the calibration data provided in the image header file. All images were processed using the ENVI 5.2 software.

ISODATA unsupervised classification was performed on all images to yield 22 classes for water and 25 for land. Validation of the classes was conducted by selecting random points for each habitat class in the area of study around Hurghada. Ground truth field work was conducted over a period of 10 days in 2013. About 150 reference points (Figure 2) were selected in the study area using GPS points for validation of the image data. A supervised classification was then conducted by selecting specific data at these pixel locations. The supervised classification was performed using a maximum likehood algorithm (ENVI 5.2 software).

The change detection analysis was performed using the results of the supervised classification of all satellite images from (1973-2015). Results of the supervised classification were converted into vector layers using ENVI 5.0 software, and Arc GIS $10.3^{\mathrm{TM}}$ was used to perform a contextual editing for each class to complete the calculation of class's areas. The difference in area of each class in sequential satellite images was then computed in Arc GIS.

Descriptive analysis performed by IBM SPSS software package (Version 17) was used to test the present water quality and fish production data while the graphs were performed by Microsoft excel. 


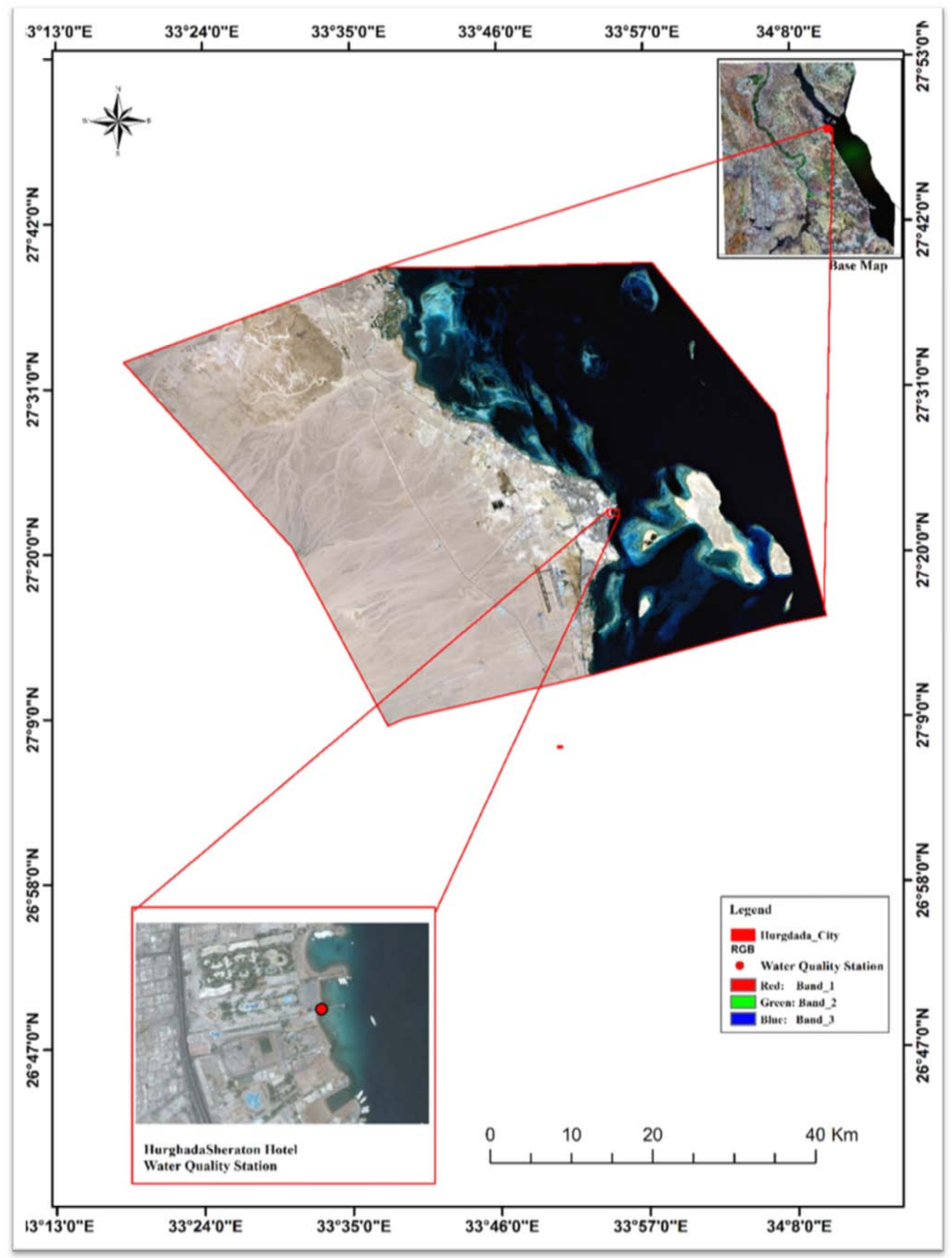

Figure 1. Landsat satellite image indicating the location of the study area in the Red Sea. Red dot indicate water quality station. 


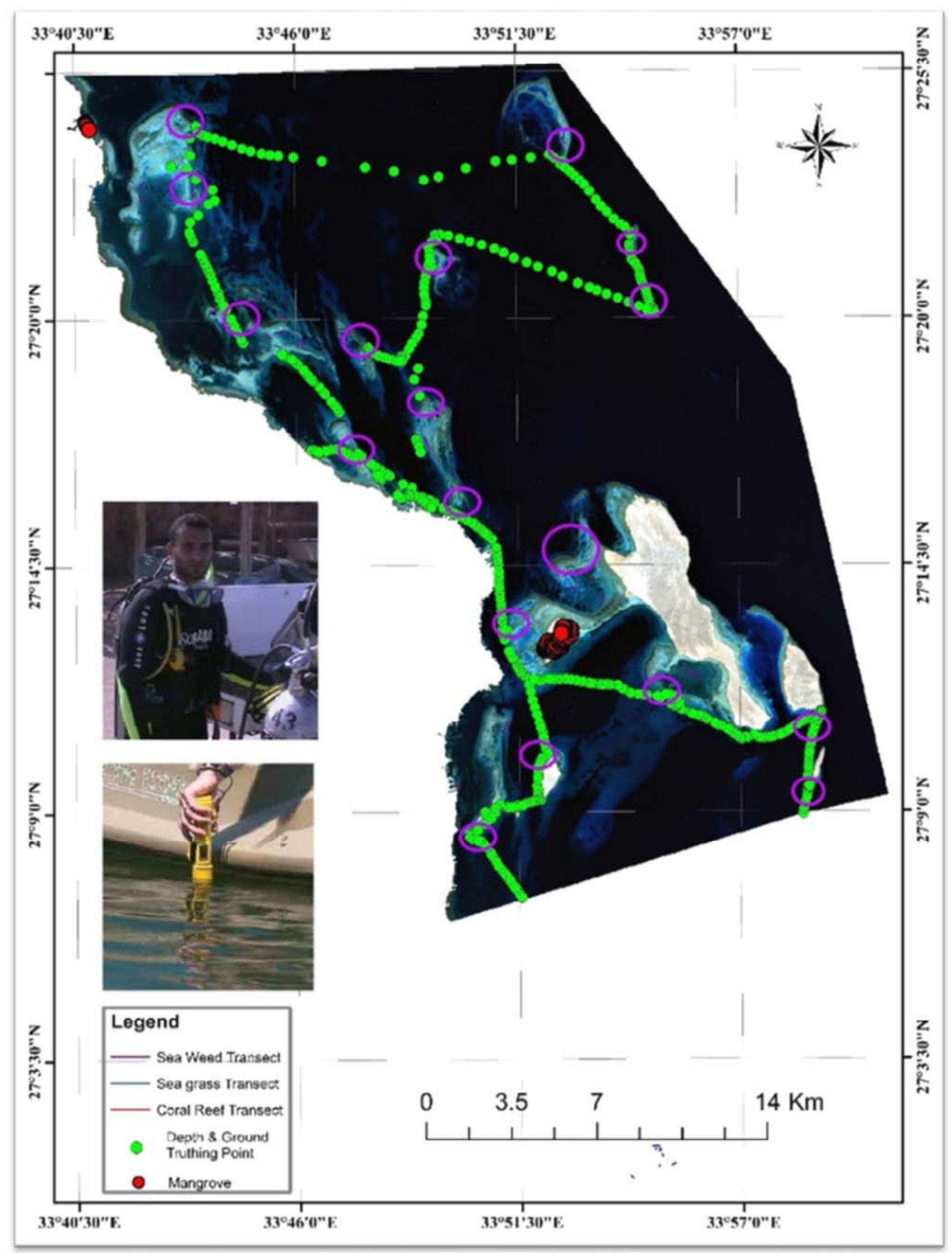

Figure 2. Landsat satellite image indicating location of field trip sampling for ground truth data. Green dot indicates depth and ground truth point; Red dot indicates Mangrove forest and purple circles show the location of transects for in situ coral cover and habitat assessments. 
Table 1. Remote sensing images from the Landsat sensors used in the present study.

\begin{tabular}{llll}
\hline Sensor & Path/Row & Acquisition Date & Resolution \\
\hline Landsat MSS & $187 / 41$ & $30-06-1973$ & $79 / 82$ \\
Landsat TM_4 & $174 / 41$ & $03-08-1992$ & $30-120(\mathrm{~B} 6)$ \\
& & $21-08-1984$ & $08-04-1987$ \\
& & $12-08-1998$ & $14-06-2000$ \\
Landsat TM_5 & $174 / 41$ & $11-09-2003$ & $30-120(\mathrm{~B} 6)$ \\
& & $03-12-2010$ & $10-07-2015$ \\
\hline
\end{tabular}

Table 2. Landsat sensor spectral bands.

\begin{tabular}{llll}
\hline Band & OLI_TIRS+ $(\boldsymbol{\mu m})$ & TM, ETM+ $(\boldsymbol{\mu m})$ & MSS $(\boldsymbol{\mu m})$ \\
\hline 1 & $0.433-0.453$ & $0.45-0.52$ & $0.5-0.6$ \\
2 & $0.450-0.515$ & $0.52-0.60$ & $0.6-0.7$ \\
3 & $0.525-0.600$ & $0.63-0.69$ & $0.7-0.8$ \\
4 & $0.630-0.680$ & $0.76-0.90$ & $0.8-1.1$ \\
5 & $0.845-0.885$ & $1.55-1.75$ & - \\
6 & $1.560-1.660$ & $10.40-12.50$ & - \\
7 & $2.100-2.300$ & $2.08-2.35$ & - \\
8 & $0.500-0.680$ & $0.52-0.90$ & - \\
9 & $1.360-1.390$ & - & - \\
10 & $10.6-11.2$ & - & - \\
11 & $11.5-12.5$ & - & - \\
\hline
\end{tabular}

Table 3. Change in Land use/Land cover and coral reef cover from 1973 to 2015.

\begin{tabular}{|c|c|c|c|c|c|}
\hline \multirow{2}{*}{$\begin{array}{l}\text { Class Change } \\
\text { Year }\end{array}$} & \multirow{2}{*}{ Urban $/ \mathbf{K m}^{2}$} & \multirow{2}{*}{ Road Length/Km } & \multicolumn{2}{|c|}{ Shore Line $\backslash \mathrm{Km}^{2}$} & \multirow{2}{*}{ Coral Reef/Km ${ }^{2}$} \\
\hline & & & Accretion & Erosion & \\
\hline $1973-1984$ & 0.8 & 68.5 & 0.4 & 0.03 & -0.61 \\
\hline $1984-1987$ & 0.9 & 29.8 & 0.18 & 0.09 & -0.8 \\
\hline $1987-1992$ & 1.2 & 43.25 & 1.84 & 0.59 & -1.29 \\
\hline $1992-1998$ & 1.1 & 43.78 & 0.64 & 0.02 & -0.41 \\
\hline $1998-2000$ & 0.5 & 27.26 & 0.65 & 0.47 & -0.4 \\
\hline $2000-2003$ & 2.1 & 30.78 & 0.41 & 0.07 & -1.19 \\
\hline $2003-2010$ & 3.7 & 52.54 & 0.54 & 0.93 & -0.42 \\
\hline $2010-2015$ & 3.1 & 86.84 & 0.2 & 0.18 & -1.08 \\
\hline $1973-2015$ & 13.4 & 382.76 & 3.5 & 1.03 & -6.21 \\
\hline
\end{tabular}

\section{Results}

\subsection{Shoreline Changes}

Table 4. Surface area $\left(\mathrm{Km}^{2}\right)$ of Land use/Land cover and coral reef cover between 1973 and 2015 estimated from the Landsat data.

\begin{tabular}{llll}
\hline $\begin{array}{l}\text { Classes } \\
\text { Year }\end{array}$ & $\begin{array}{l}\text { Urban } \\
\text { Area/Km } \mathbf{K m}^{2}\end{array}$ & $\begin{array}{l}\text { Road } \\
\text { Length/Km }\end{array}$ & $\begin{array}{l}\text { Coral } \\
\mathbf{A r e a}_{\mathbf{K}} \mathbf{K m}^{2}\end{array}$ \\
\hline 1973 & 1.9 & 126.195 & 17.09 \\
1984 & 2.7 & 194.695 & 16.48 \\
1987 & 3.6 & 224.495 & 15.68 \\
1992 & 4.8 & 267.752 & 14.39 \\
1998 & 5.9 & 311.531 & 13.98 \\
2000 & 6.4 & 338.789 & 13.58 \\
2003 & 8.5 & 369.566 & 12.38 \\
2010 & 12.2 & 422.110 & 11.96 \\
2015 & 15.3 & 508.953 & 10.88 \\
\hline
\end{tabular}

Changes in the shoreline around Hurghada have occurred primarily due to coastal development, including dredging and landfilling. Changes in urban area and road length along this shoreline over the past 42 years are shown in Table 4 and Figures 3 through 7 . The change in land area along the shoreline from 1973 to 1984 was about $0.4 \mathrm{~km}^{2} /$ year. There was also erosion over the same period of $0.3 \mathrm{~km}^{2} /$ year primarily in the northwest sector of the study region. The total accretion of land was $+3.5 \mathrm{~km}^{2}$ from 1973 to 2015 , while the total change rate of erosion was $+1.03 \mathrm{~km}^{2}$. At the beginning of the high-development period, when the tourism industry accelerated between 1984 and 1987, the land accretion rate was about $+0.18 \mathrm{~km}^{2}$ and erosion rate about $+0.097 \mathrm{~km}^{2}$. 


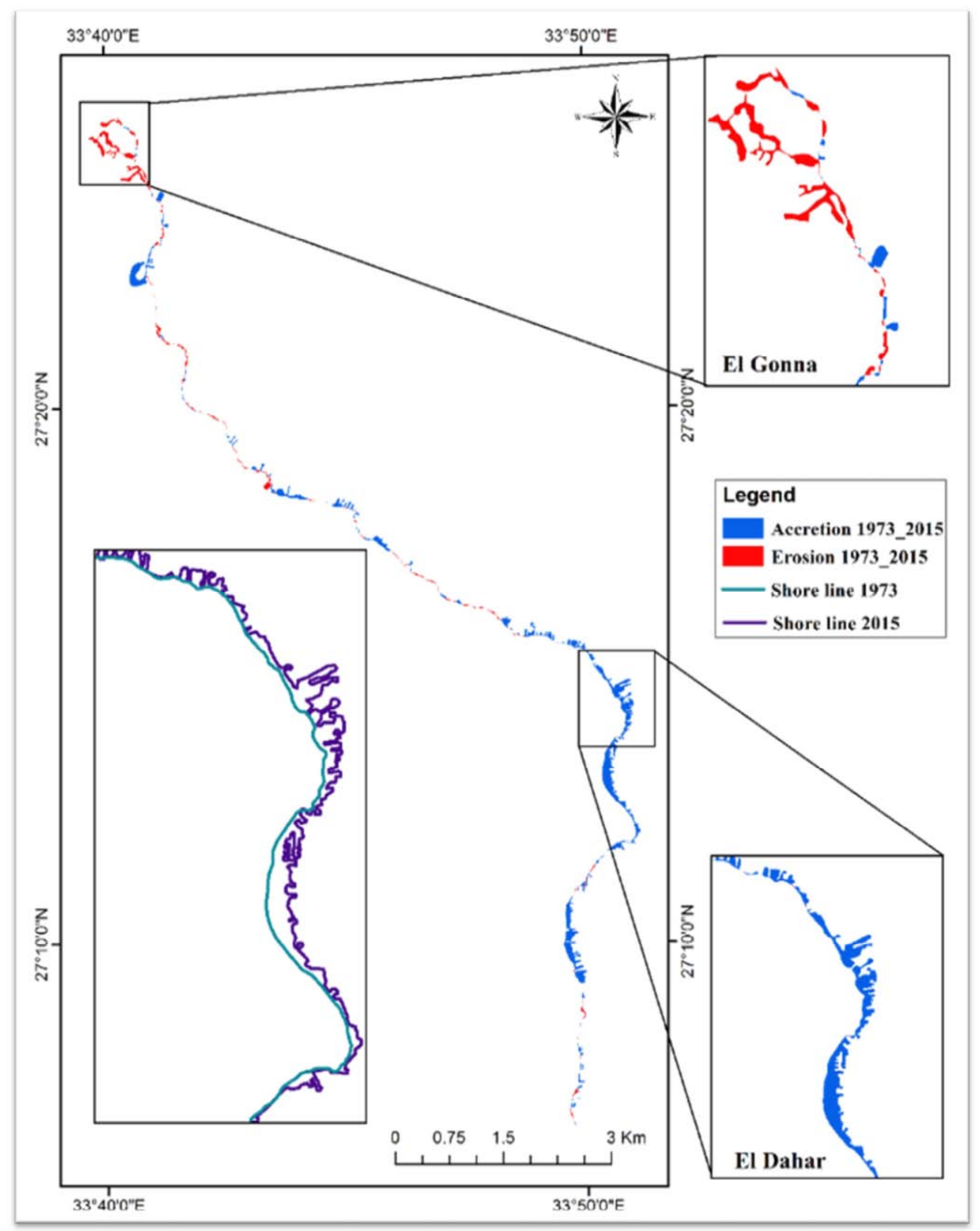

Figure 3. Changes in the shoreline near Hurghada between 1973 and 2015. 


\subsection{Urban and Road Changes}

Changes in urban area and road length in the 42 years studied are shown in Tables 3 and 4 and in Figure $4 \& 6$. Urban area at 1973 was about $1.9 \mathrm{~km}^{2}$, but it reached 15.3 $\mathrm{km}^{2}$ in 2015 (a change of $+13.4 \mathrm{~km}^{2}$ in 42 years). The overall length of the road network was about $126.2 \mathrm{~km}$ in 1973, and it reached $509.0 \mathrm{~km}$ over the period 1973-2015 (a change of $+382.8 \mathrm{~km})$.

\subsection{Coral Reef Cover}

The data obtained from the satellite images show that coral reef cover in the study area decreased by $6.2 \mathrm{Km}^{2}$ from 1973 to 2015 (Figure $5 \& 6$, Table 3), following a linear trend:

$y=-0.1564 x+326.28$, where ' $x$ ' is the year

\subsection{Water Quality}

Descriptive analysis of water quality indicators including dissolved oxygen concentration (mg/l), chlorophyll-a concentration $(\mu \mathrm{g} / \mathrm{l})$, total suspended matter $(\mathrm{mg} / \mathrm{l})$, transparency $(\mathrm{m})$, total nitrogen $(\mathrm{mg} / \mathrm{l})$, nitrate $(\mu \mathrm{g} / \mathrm{l})$, nitrite $(\mu \mathrm{g} / \mathrm{l})$, ammonia $(\mu \mathrm{g} / \mathrm{l})$, phosphate $(\mu \mathrm{g} / \mathrm{l})$, total phosphorus, and silicate $(\mu \mathrm{g} / \mathrm{l})$, were recorded every year at Hurghada Sheraton hotel station (Figure 1) during the period from 1998 till 2012 as shown in (Table 7,8) and graph (Figure 8).

Table (4): Surface area $\left(\mathrm{Km}^{2}\right)$ of Land use/Land cover and coral reef cover between 1973 and 2015 estimated from the Landsat data.

The result shows that the high annual mean of dissolved oxygen, chlorophyll-a, total suspended matter, nitrate and nitrite were: $(7.6 \pm 1.07 \mathrm{mg} / \mathrm{l}),(0.85 \pm 0.45 \mu \mathrm{g} / \mathrm{l}),(22 \pm 2.6$ $\mathrm{mg} / \mathrm{l}),(4.17 \pm 1.02 \mu \mathrm{g} / \mathrm{l})$ and $(11.3 \pm 2.38 \mu \mathrm{g} / \mathrm{l})$ in 2012; respectively while the low concentrations were: $(6.3 \pm 0.21$ $\mathrm{mg} / \mathrm{l})$ in $2003,(0.09 \pm 0.02 \mu \mathrm{g} / \mathrm{l})$ in $1999,(4.4 \pm 2.5 \mathrm{mg} / \mathrm{l})$ in $2000,(0.07 \pm 0.06 \mu \mathrm{g} / \mathrm{l})$ in 2003 and $(0.02 \pm 0.02 \mu \mathrm{g} / \mathrm{l})$ in 1998 : respectively. The high annual means of phosphate, total phosphorus and silicate were: $(1.06 \pm 0.82 \mu \mathrm{g} / \mathrm{l}),(34.1 \pm 13.2$ $\mu \mathrm{g} / \mathrm{l})$ and $(55.7 \pm 15.4 \mu \mathrm{g} / \mathrm{l})$ in 2011 ; respectively while the low concentrations were: $(0.03 \pm 0.01 \mu \mathrm{g} / \mathrm{l})$ in $1998,2001,2002$, 2004, 2006, 2007and 2008, $(0.53 \pm 0.26 \mu \mathrm{g} / \mathrm{l})$ in 2001 and $(0.68 \pm 0.18 \mu \mathrm{g} / \mathrm{l})$ in 2005 ; respectively. The high annual means of transparency, total nitrogen and ammonia were: $(7.3 \pm 0.8 \mathrm{~m})$ in $2005,(530 \pm 53 \mu \mathrm{g} / \mathrm{l})$ in 1998 and $(12.6 \pm 11.6$ $\mu \mathrm{g} / \mathrm{l})$ in 2010; respectively while the low concentrations were: $(3.9 \pm 1.0 \mathrm{~m})$ in $2001,(0.8 \pm 0.5 \mu \mathrm{g} / \mathrm{l})$ in 2010 and $(0.26 \pm 0.41 \mu \mathrm{g} / \mathrm{l})$ in 1998 ; respectively.

\subsection{Total Economic Value of Coral Reefs and Fish Loss}

Ahmed and Serour estimated the cost of destroying a square meter of coral reef at US\$3000 of annual income [2], [10]. Also, Ngoc estimated the loss economic value of reefbuilding coral in response to global climate change and fishing effort scenarios which ranges from US\$28 to US\$32 million annually [31]. This means that the loss of coral reef cover around Hurghada represents a total economic loss of US\$18.630 Billion over the period 1973 to 2015 (Table 5). It is also estimated that $1 \mathrm{~km}^{2}$ (about 250 acres) of high quality reef can sustainably produce an average of 15 tons ( 1 metric ton $=2205 \mathrm{lb}$ ) of fish each year [32]. Table 5 and Figure 7 show estimated fish production between 1973 and 2015. Figure 7 and table 6 shows the change recorded in the annual reports of GAFRD from 1991 to 2007, which show the total decrease and increase for the whole Red sea fish production.

Table 5. Total economic value (TEV) of coral reefs and the expected fishery production based on coral reef area from 1973 to 2015.

\begin{tabular}{lll}
\hline Year & Expected Fish production/tons & Coral Reef TEV/\$/Billion \\
\hline 1973 & 256.35 & 51,270 \\
1984 & 247.2 & 49,440 \\
1987 & 235.2 & 47,040 \\
1992 & 215.85 & 43,170 \\
1998 & 209.7 & 41,940 \\
2000 & 203.7 & 40,740 \\
2003 & 185.7 & 37,140 \\
2010 & 179.4 & 35,880 \\
2015 & 163.2 & 32,640 \\
\hline
\end{tabular}

Table 6. Annual fish production along the Egyptian Red sea coast (Hurghada City) reported by the GAFRD.

\begin{tabular}{|c|c|c|c|c|c|c|c|c|c|c|c|c|c|c|c|c|c|}
\hline Year & 1991 & 1992 & 1993 & 1994 & 1995 & 1996 & 1997 & 1998 & 1999 & 2000 & 2001 & 2002 & 2003 & 2004 & 2005 & 2006 & 2007 \\
\hline Prod. & 41.94 & 43.4 & 50.9 & 48.4 & 47.3 & 48.5 & 57.4 & 57.1 & 82.4 & 75.97 & 73.5 & 72.9 & 70.4 & 63.9 & 50.7 & 46.9 & 47 \\
\hline
\end{tabular}

Table 7. Annual means $\pm S D$ of water quality at the study area during the period of investigation $(n=12)$.

\begin{tabular}{|c|c|c|c|c|c|c|c|c|c|c|c|c|}
\hline Year & & D. O.mg/l & Chl-a $\mu \mathrm{g} / \mathrm{l}$ & TSM mg/l & T.m & T. N. $\mu \mathrm{g} / \mathrm{l}$ & $\mathrm{NO}_{3} \mu \mathrm{g} / \mathrm{l}$ & $\mathrm{NO}_{2} \mu \mathrm{g} / \mathrm{l}$ & $\mathrm{NH}_{4} \mu \mathrm{g} / \mathrm{l}$ & $\mathrm{PO}_{4} \mu \mathrm{g} / \mathrm{l}$ & T. P. $\mu \mathrm{g} / \mathbf{l}$ & $\mathrm{SiO}_{4} \mu \mathrm{g} / \mathrm{l}$ \\
\hline \multirow[t]{2}{*}{1998} & M & 6.7 & 0.14 & 4.9 & 5.5 & 530 & 0.55 & 0.02 & 0.26 & 0.03 & 1.47 & 1.54 \\
\hline & $\mathrm{SD}$ & 0.86 & 0.08 & 0.3 & 0.5 & 53 & 0.12 & 0.02 & 0.41 & 1.09 & 0.11 & 0.28 \\
\hline \multirow[t]{2}{*}{1999} & M & 7.27 & 0.09 & 6.7 & 5 & 178 & 0.25 & 0.03 & 0.84 & 0.09 & 0.8 & 1.67 \\
\hline & $\mathrm{SD}$ & 0.27 & 0.02 & 2.3 & 0.4 & 266 & 0.14 & 0.02 & 0.7 & 0.06 & 0.51 & 0.13 \\
\hline
\end{tabular}




\begin{tabular}{|c|c|c|c|c|c|c|c|c|c|c|c|c|}
\hline Year & & D. O.mg/l & Chl-a $\mu \mathrm{g} / \mathrm{l}$ & TSM mg/l & T.m & T. N. $\mu \mathrm{g} / \mathbf{l}$ & $\mathrm{NO}_{3} \mu \mathrm{g} / \mathbf{l}$ & $\mathrm{NO}_{2} \mu \mathrm{g} / \mathrm{l}$ & $\mathrm{NH}_{4} \mu \mathrm{g} / \mathbf{l}$ & $\mathrm{PO}_{4} \mu \mathrm{g} / \mathrm{l}$ & T. P. $\mu \mathrm{g} / \mathrm{I}$ & $\mathrm{SiO}_{4} \mu \mathrm{g} / \mathrm{l}$ \\
\hline \multirow[t]{2}{*}{2000} & M & 7.05 & 0.16 & 4.4 & 4.6 & 317 & 0.15 & 0.15 & 0.61 & 0.09 & 0.93 & 1.53 \\
\hline & SD & 0.6 & 0.09 & 2.5 & 1.2 & 310 & 0.17 & 0.14 & 0.56 & 0.05 & 0.48 & 0.57 \\
\hline \multirow[t]{2}{*}{2001} & M & 6.83 & 0.13 & 7.9 & 3.9 & 21 & 0.12 & 0.4 & 0.68 & 0.03 & 0.53 & 1.61 \\
\hline & SD & 0.2 & 0.05 & 1.1 & 1 & 8.8 & 0.16 & 0.17 & 0.46 & 0.02 & 0.26 & 0.68 \\
\hline \multirow[t]{2}{*}{2002} & M & 6.98 & 0.19 & 6.2 & 5.6 & 14 & 0.08 & 0.22 & 0.62 & 0.03 & 0.8 & 0.87 \\
\hline & SD & 0.31 & 0.22 & 0.5 & 0.4 & 5.6 & 0.07 & 0.12 & 0.41 & 0.01 & 0.36 & 0.31 \\
\hline \multirow[t]{2}{*}{2003} & M & 6.34 & 0.16 & 6.4 & 5 & 27 & 0.07 & 0.68 & 0.6 & 0.07 & 0.64 & 0.84 \\
\hline & SD & 0.21 & 0.07 & 0.6 & 0.4 & 11 & 0.06 & 0.41 & 0.37 & 0.02 & 0.24 & 0.31 \\
\hline \multirow[t]{2}{*}{2004} & M & 7.27 & 0.34 & 7.1 & 5.4 & 23 & 0.09 & 0.45 & 0.41 & 0.03 & 0.63 & 0.97 \\
\hline & SD & 0.7 & 0.19 & 0.8 & 0.2 & 12 & 0.07 & 0.14 & 0.18 & 0.01 & 0.13 & 0.62 \\
\hline \multirow[t]{2}{*}{2005} & M & 7.61 & 0.84 & 8.4 & 7.3 & 32 & 0.15 & 0.52 & 0.77 & 0.07 & 0.62 & 0.68 \\
\hline & SD & 0.62 & 0.24 & 1.2 & 0.8 & 8.7 & 0.07 & 0.29 & 0.33 & 0.03 & 0.29 & 0.18 \\
\hline \multirow[t]{2}{*}{2006} & M & 7.29 & 0.39 & 9.5 & 7.1 & 29 & 0.09 & 0.66 & 0.52 & 0.03 & 0.58 & 0.93 \\
\hline & SD & 0.28 & 0.11 & 1 & 0.7 & 11 & 0.08 & 0.34 & 0.14 & 0.01 & 0.2 & 0.24 \\
\hline \multirow[t]{2}{*}{2007} & $\mathrm{M}$ & 6.34 & 0.18 & 7.3 & 4.9 & 39 & 0.16 & 0.73 & 0.69 & 0.03 & 0.72 & 1.19 \\
\hline & SD & 1.07 & 0.09 & 1.4 & 2.2 & 17 & 0.04 & 0.49 & 0.35 & 1.09 & 0.27 & 0.36 \\
\hline \multirow[t]{2}{*}{2008} & $\mathrm{M}$ & 7.48 & 0.16 & 20 & 5.4 & 57 & 0.19 & 0.58 & 0.84 & 0.03 & 0.81 & 1.91 \\
\hline & SD & 0.83 & 0.08 & 3.6 & 0.2 & 14 & 0.05 & 0.13 & 0.31 & 0.02 & 0.33 & 0.32 \\
\hline \multirow[t]{2}{*}{2009} & $\mathrm{M}$ & 7.36 & 0.41 & 13 & 6.1 & 45 & 0.26 & 0.95 & 0.71 & 0.05 & 0.95 & 2.16 \\
\hline & SD & 0.39 & 0.28 & 1.7 & 1.7 & 8.7 & 0.13 & 0.12 & 0.43 & 0.04 & 0.28 & 0.47 \\
\hline \multirow[t]{2}{*}{2010} & $\mathrm{M}$ & 6.91 & 0.21 & 15 & 4.8 & 0.8 & 1.94 & 5.79 & 12.6 & 0.61 & 8.34 & 12.9 \\
\hline & SD & 0.5 & 0.27 & 4.3 & 0.6 & 0.5 & 1.34 & 3.24 & 11.6 & 0.44 & 5.18 & 11 \\
\hline \multirow[t]{2}{*}{2011} & $\mathrm{M}$ & 7.43 & 0.36 & 15 & 4.4 & 1.3 & 1.86 & 10.7 & 10.8 & 1.06 & 34.1 & 55.7 \\
\hline & SD & 0.41 & 0.17 & 4.7 & 1.1 & 0.5 & 0.63 & 4.79 & 7.31 & 0.82 & 13.2 & 15.4 \\
\hline \multirow[t]{2}{*}{2012} & $\mathrm{M}$ & 7.63 & 0.85 & 22 & 4.2 & 206 & 4.17 & 11.3 & 11.9 & 0.65 & 27.5 & 54.8 \\
\hline & SD & 1.07 & 0.45 & 2.6 & 0.6 & 18 & 1.02 & 2.38 & 3.64 & 0.18 & 10.9 & 18.6 \\
\hline
\end{tabular}

Mean $=$ M, Standard Deviation $=$ SD, Dissolved Oxygen= D. O., Chlorophyll-a $=$ Chl-a, Total Suspended Matter $=$ T.S.M., Transparency $=$ T., Total Nitrogen $=$ T. N., Nitrate $=\mathrm{NO}_{3}$, Nitrite $=\mathrm{NO}_{2}, \mathrm{Ammonia}=\mathrm{NH}_{4}$, Phosphate $=\mathrm{PO}_{4}$, Total Phosphorus $=$ T. P., Silicate $=\mathrm{SiO}_{4}$

Table 8. Annual mean changes of water quality at the study area.

\begin{tabular}{|c|c|c|c|c|c|c|c|c|c|c|c|}
\hline Year & D. O. $\mathrm{mg} / \mathrm{l}$ & Chl-a $\mu \mathrm{g} / \mathrm{l}$ & TSM mg/l & T. $\mathrm{m}$ & T. N. $\mu \mathrm{g} / \mathrm{l}$ & $\mathrm{NO}_{3} \mu \mathrm{g} / \mathrm{I}$ & $\mathrm{NO}_{2} \mu \mathrm{g} / \mathrm{l}$ & $\mathrm{NH}_{4} \mu \mathrm{g} / \mathrm{l}$ & $\mathrm{PO}_{4} \mu \mathrm{g} / \mathrm{l}$ & T. P. $\mu \mathrm{g} / \mathrm{l}$ & $\mathrm{SiO}_{4} \mu \mathrm{g} / \mathrm{l}$ \\
\hline 98-99 & 0.59 & -0.05 & 1.8 & -0.5 & -351 & -0.3 & 0.01 & 0.58 & 0.06 & -0.67 & 0.13 \\
\hline $99-00$ & -0.25 & 0.07 & -2.3 & -0.4 & 138 & -0.1 & 0.12 & -0.23 & 0.01 & 0.13 & -0.14 \\
\hline 00-01 & -0.22 & -0.03 & 3.48 & -0.8 & -296 & -0.04 & 0.25 & 0.08 & -0.06 & -0.4 & 0.08 \\
\hline 01-02 & 0.15 & 0.05 & -1.7 & 1.8 & -7.24 & -0.04 & -0.2 & -0.06 & -0.01 & 0.27 & -0.74 \\
\hline $02-03$ & -0.65 & -0.03 & 0.2 & -0.6 & 3.61 & -0.01 & 0.46 & -0.02 & 0.05 & -0.16 & -0.03 \\
\hline 03-04 & 0.97 & 0.18 & 0.73 & 0.4 & -4.36 & 0.021 & -0.2 & -0.19 & -0.04 & -0.01 & 0.13 \\
\hline 04-05 & 0.31 & 0.5 & 1.23 & 1.9 & 9.03 & 0.065 & 0.07 & 0.37 & 0.04 & -0.01 & -0.29 \\
\hline 05-06 & -0.32 & -0.45 & 1.13 & -0.1 & -3.32 & -0.07 & 0.14 & -0.26 & -0.03 & -0.04 & 0.25 \\
\hline 06-07 & -0.95 & -0.22 & -2.2 & -2.3 & 9.91 & 0.074 & 0.07 & 0.18 & -0.01 & 0.14 & 0.26 \\
\hline 07-08 & 1.14 & -0.02 & 12.9 & 0.5 & 18.5 & 0.026 & -0.2 & 0.15 & 0.001 & 0.09 & 0.72 \\
\hline 08-09 & -0.12 & 0.25 & -7.5 & 0.8 & -12.2 & 0.071 & 0.37 & -0.14 & 0.021 & 0.14 & 0.25 \\
\hline $09-10$ & -0.45 & -0.2 & 2.61 & -1.4 & -44.3 & 1.685 & 4.84 & 11.9 & 0.56 & 7.39 & 10.7 \\
\hline $10-11$ & 0.52 & 0.15 & -0.3 & -0.4 & 0.52 & -0.08 & 4.92 & -1.79 & 0.45 & 25.7 & 42.8 \\
\hline $11-12$ & 0.2 & 0.49 & 6.51 & -0.2 & 205 & 2.31 & 0.63 & 1.16 & -0.41 & -6.58 & -0.88 \\
\hline $98-12$ & 0.92 & 0.71 & 16.6 & -1.3 & -323 & 3.616 & 11.3 & 11.7 & 0.63 & 26 & 53.3 \\
\hline
\end{tabular}

Mean $=$ M, Standard Deviation $=$ SD, Dissolved Oxygen= D. O., Chlorophyll-a $=$ Chl-a, Total Suspended Matter= T.S.M., Transparency=T., Total Nitrogen $=$ T. N., Nitrate $=\mathrm{NO}_{3}$, Nitrite $=\mathrm{NO}_{2}$, Ammonia $=\mathrm{NH}_{4}$, Phosphate $=\mathrm{PO}_{4}$, Total Phosphorus $=$ T. P., Silicate $=\mathrm{SiO}_{4}$ 


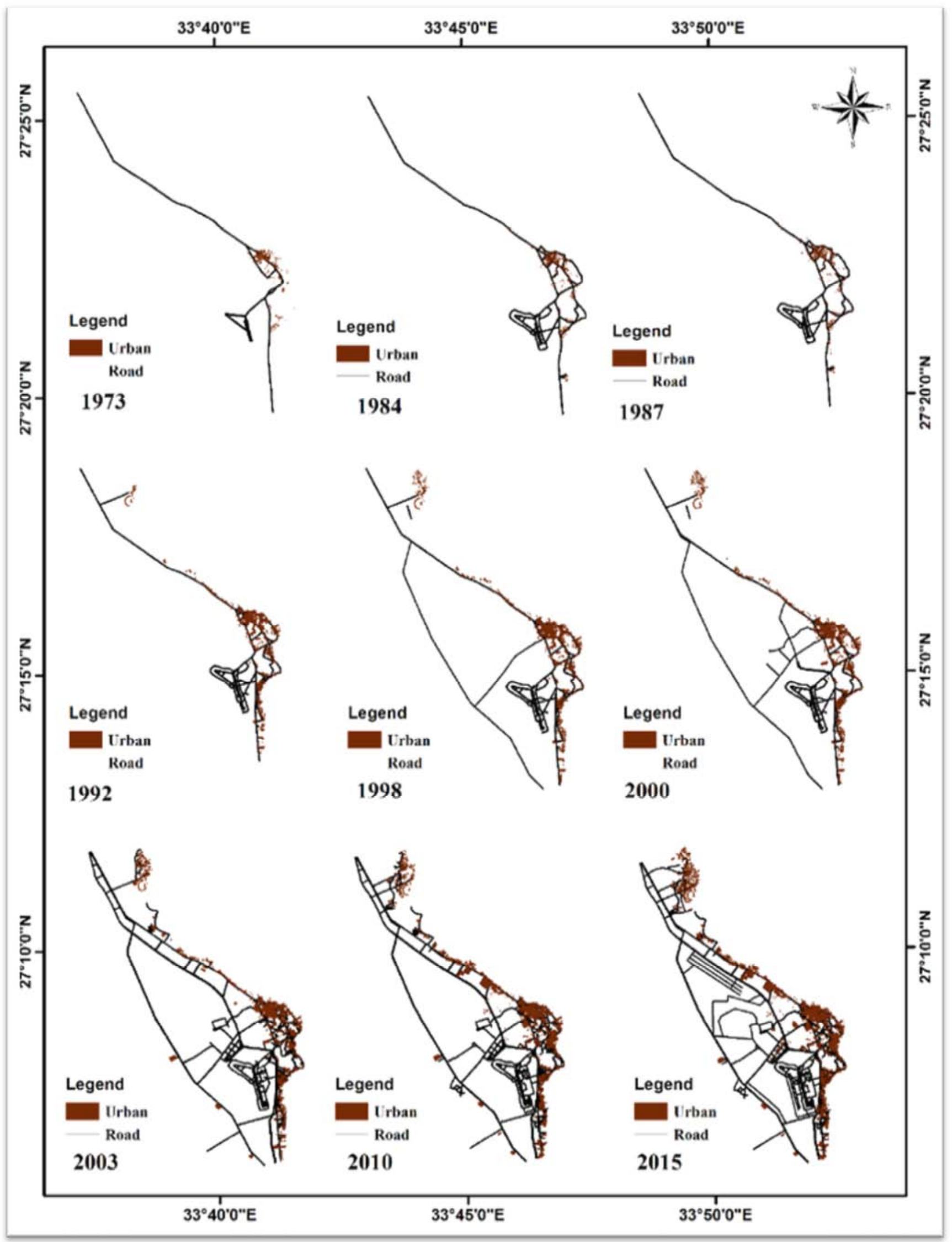

Figure 4. Changes in urban area and in the road network around Hurghada between 1973 and 2015. 


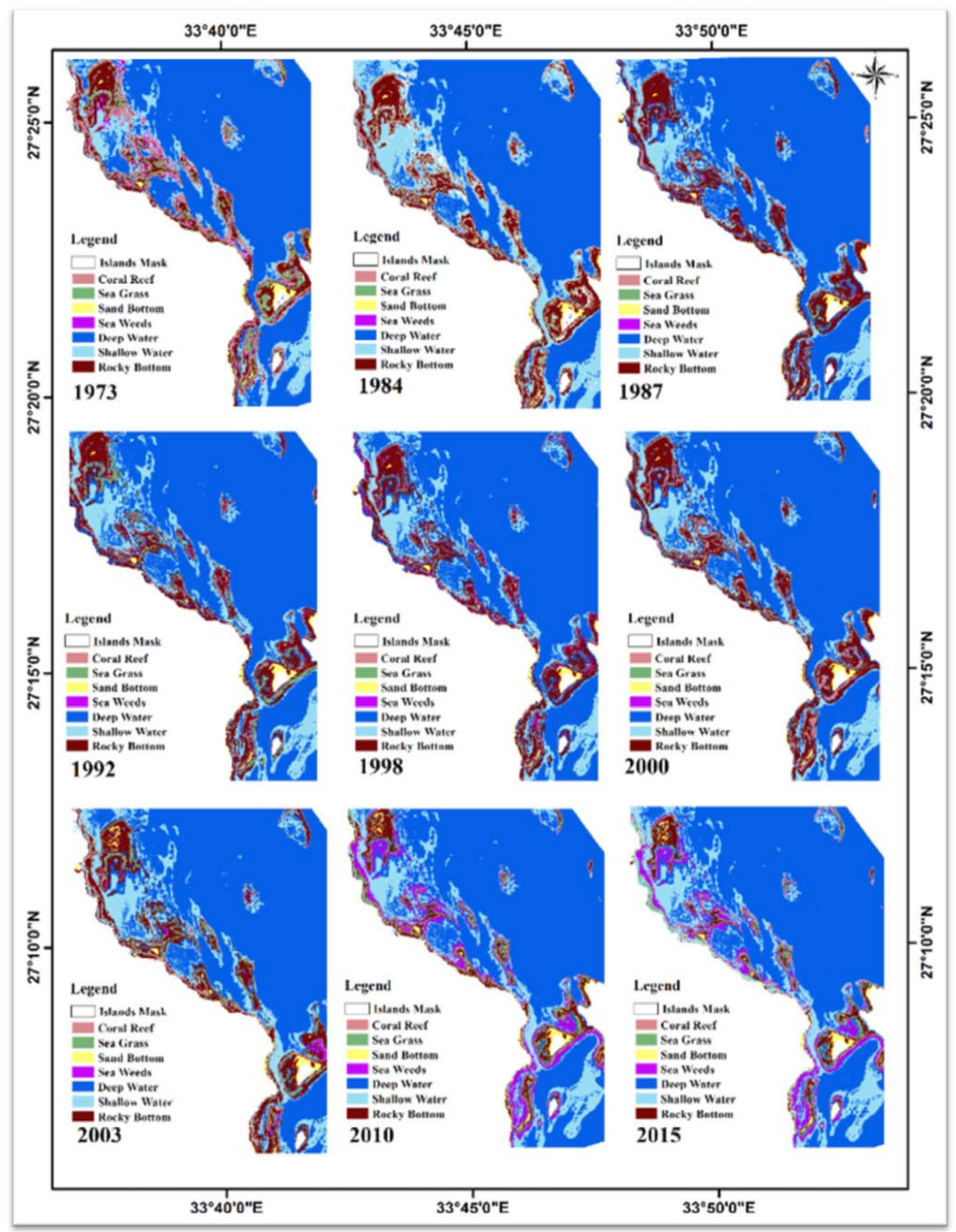

Figure 5. Supervised classification of benthic habitat changes between 1973 and 2015. 


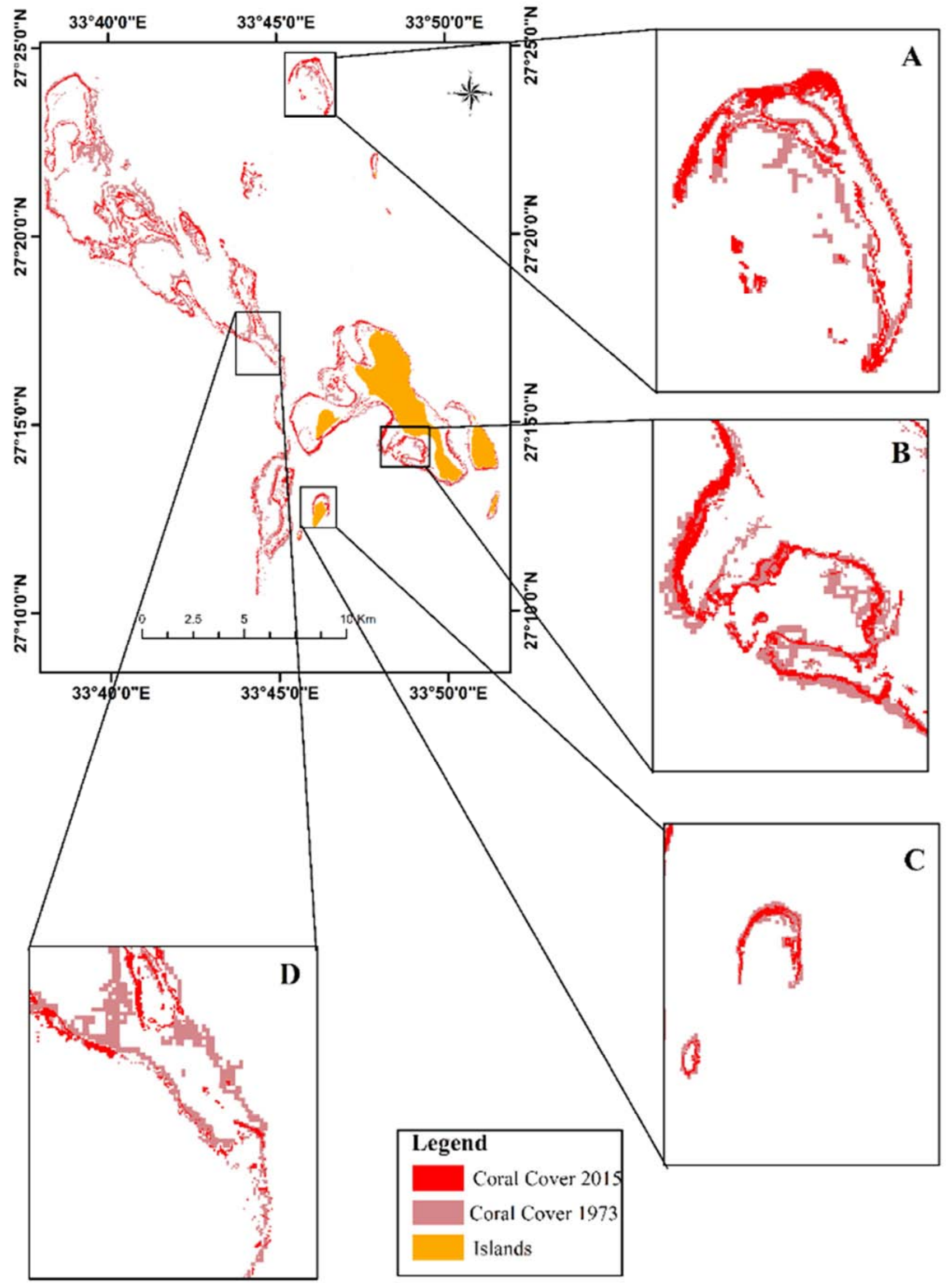

Figure 6. Coral reef cover changes between 1973 and 2015. A: show the El Erg batch reef, B: Show the Big Giftun reef, C: show the small and big Magawish island reef, and D: show the fringing reef at Dahar area. 

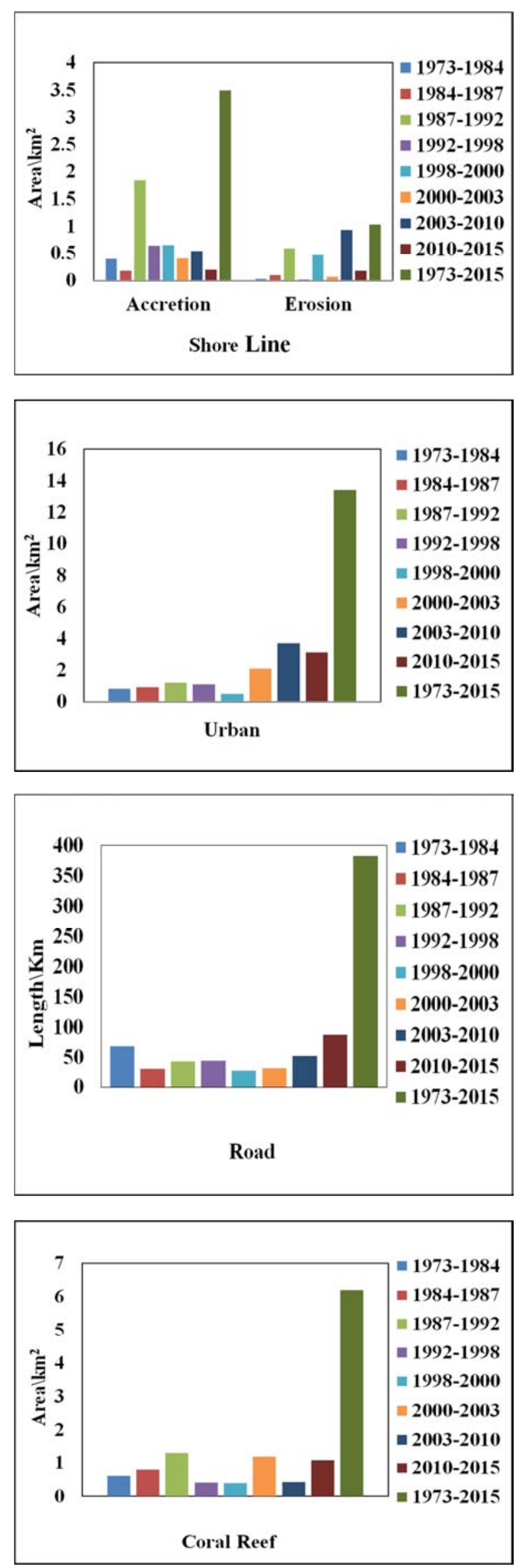
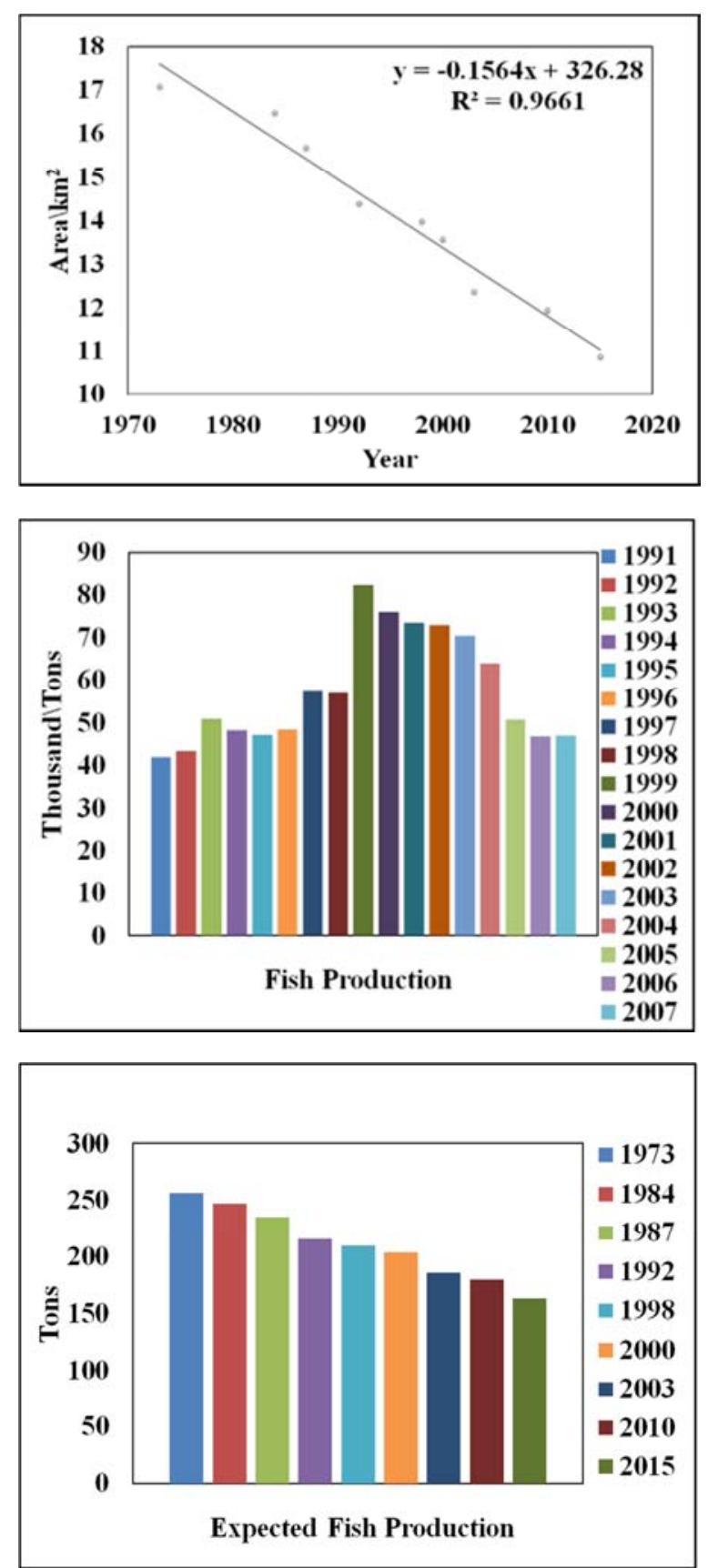

Figure 7. Change in coastal area along the shoreline (upper left) and in urban (upper middle), road (upper right), and coral reef (center left) area cover. Coral cover has declined in linear fashion over time (center middle). Fish production from GAFRD (center right) and expected fish production from satellite data (lower left) are shown.

\section{Discussion}

Satellite images showed a decrease in coral reef cover of $6.2 \mathrm{Km}^{2}$ while coastal line (accretion and erosion) was estimated at $4.53 \mathrm{~km}^{2}$, urban development increased about $13.4 \mathrm{~km}^{2}$, and the increase in road length was estimated at $382.76 \mathrm{~km}$ over the past 42 years (1973 to 2015). Vanderstraete et al made a change detection map for coral reef habitat in the Hurghada area (from El Gouna to Sahel 
Hashish) for the 13-year period spanning 1987 to 2000 using Landsat (TM, ETM+) images [33]. The authors found that coral reef area decreased about $6 \mathrm{~km}^{2}$, because the entire area was about $60 \mathrm{~km}$ in length, while the area used in the current study is $46 \mathrm{~km}$ in length and the shore line, urban area, and road network length increased $6.0 \mathrm{~km}^{2}$ (Landfilling $4.0 \mathrm{~km}^{2}$ and dredging $2.0 \mathrm{~km}^{2}$ ), $26.2 \mathrm{~km}^{2}$, and $144.5 \mathrm{~km}$, respectively.

Similarly, El-Gamily et al. examined the landfill areas that are common around the Hurghada and Safaga area, using two Landsat TM-images, collected 7 years apart (1984 and 1991). They have noticed $2.14 \mathrm{~km}^{2}$ decrease in the coral reef area, while landfill area along the shore line increased by 3.95 $\mathrm{km}^{2}$, and total urban area increased by $3.7 \mathrm{~km}^{2}$ [34]. Results of our study are in consistent with the above-mentioned studies. The change due to the urban expansion of the Hurghada area (from El Gouna to Sahel Hashish) has been also estimated by other research group [35]. They monitored the changeover a time period of18-years from 1987 to 2005using Landsat (TM, ETM+) and ASTER images. The authors reported that coral reef area decreased $25.29 \mathrm{~km}^{2}$ from 1987 to 2005, while the landfill and urban area increased $4.5 \mathrm{~km}^{2}, 23.67 \mathrm{~km}^{2}$, respectively. Likewise, Kamh et al. made a landfill detection for the Hurghada (from El Gouna to Sahel Hashish) area based on two Landsat TMimages during 13 years from 1984-1997 [36]. He calculated the total decrease of coral reef area to be about $13.45 \mathrm{~km}^{2}$ while the landfilling and urban increased $2.3 \mathrm{~km}^{2}$ and 11.86 $\mathrm{km}^{2}$ at the same period.

Moufaddal calculated the total area of landfilling and dredging in the coastal strip from north of Hurghada to south of Safaga between 1984 and 2000 as $6.5 \mathrm{~km}^{2}$. Of this area, $3.6 \mathrm{~km}^{2}$ was used as landfill and $2.9 \mathrm{~km}^{2}$ was used as the dredging area [37]. The main difference of the present study results and the other authors can be attributed to the following reasons: the length and width of the study location is smaller than the study location of the other authors (in the present study the total length $46 \mathrm{~km}$ while the other studies ranges from $65 \mathrm{~km}$ to $120 \mathrm{~km}$ in length), some of above authors didn't make water column correction, some authors did not make ground truth points for the habitat and used different techniques for change detection analyses.

Land-use related to tourism activities caused water quality changes in its condition caused shifts in the density and diversity of algae, coral reef cover and fish abundance [38] . Nutrient enrichment causing coral reef degradation and mortality across the world. Coral reefs thrive in high quality coastal waters and are sensitive to changes in water quality, such as influxes of nitrogen [39]. Naumann at al. studied the effect of nutrient on coral reefs near Dahab (Gulf of Aqaba, Red Sea) for 3 years monitoring coral reef cover and water measurement for ammonia, phosphate and nitrates and he found that the live hard coral cover declined significantly through these 3 years about $12 \%$ and increased of algal cover at this sites about $57 \%$ [40]. The study shows that ammonia, nitrate, nitrate, total phosphorus, silicate and phosphate concentration recorded the highest concentration from 2010 to 2012 while the total nitrogen concentration showed the highest concentration from 1998 to 2000 and 2012. The study of water quality in the present investigation indicated that there is a correlation between urban expansions and some parameters and coral reef decline.

The fringing coral reef ecosystem has been altered by direct impact of the changing land use/cover. Most of these changes are due to urban development mainly for tourist accommodation. Most of the dredging occurred with the construction of El Gouna resort, north of Hurghada. Landfill effects are derived from construction programs to the north and south of Hurghada. The coral reef cover around Hurghada islands was damaged from 1973 to 2015 mostly due to the heavy recreational diving as shown in Figure 5. Wilson et al. estimated that around 600,000 dives per year take place in the Hurghada area, indicated that Hurghada has approximately 60 diving centers, servicing from 13,000 to 14,000 dives per site per year at Giftun Island, Abu Ramada, Careless Reef, Sha'ab Umm Qamar, and Sha'ab Abu Nuhas [41]. Hilmi et al. indicated that most of coral reefs damages at Hurghada region came from tourism activity [9]. Also, many authors indicated that damages to the coral reefs around the Hurghada islands increased due to extensive anchoring of diving boats in the living coral reef, diving stress and fishing by dynamite [4], [34], [42-43]. Shipping and oil pollution are other anthropogenic factors which can damage the coral reef habitat. According to the Egyptian Authority for Maritime Safety (EAFMS) there were 15 incidents of ships grounded on coral reefs between 2006 and 2009. About 11 incidents of oil pollution occurred in the Hurghada area from 1998 to 2010 [44].

Based on the changes of the area in the present study during the period of 42 years (19973-2015), the loss of 6.21 $\mathrm{Km}^{2}$ of coral reefs represents a total economic loss of US\$18.6 Billion dollars. Further, there has been an estimated loss of fish production of about 93.1 tons during the period of study (1973-2015). This is corroborated by reported fish landings. Ahmed and Hilmi et al estimated the total economic value of the Egyptian Red Sea sector at US\$ 205.5 to 1,800 million, with 1,400 tons of seafood per year [2], [9]. The studies indicated that the cost of coral reefs and fisheries degradation from Hurghada to Safaga caused by unregulated tourism activities varied between US \$2,626 to 2,673 million per year.

\section{Conclusion and Recommendations}

The estimated loss of coral reef cover $\left(\sim 6.21 \mathrm{Km}^{2}\right)$ in the Hurghada area over the past 42 years (1973-2015) represents a total economic loss of US\$ 18.63 Billion dollars. This includes a loss of fish production estimated at 80.1 metric tons (1973-2015). At the current rate, coral reef cover will disappear in about 70 years (by 2086). An extensive monitoring program using the remotely sensed data should be implemented to monitor specific areas of concern due to landfilling and other impacts due to coastal development. Coral islands in the Hurghada, such as Giftun, Abu Minqar, and Magawish should be designated as protected areas. 
Reduce the recreational diving tourism. Reduce overfishing in coral areas, especially trawl fishing and dynamite. The government needs to develop buffers along the coastal zone and implement a robust coastal zone planning program, to help keep the remaining of coral reefs and other environments healthy to the extent possible.

\section{Acknowledgements}

The first author is supported by a scholarship from the Mission Department, Ministry of Higher Education of the Government of Egypt which is gratefully acknowledged. The authors would like to thank the staff of the Remote Sensing $\mathrm{Lab}$ at Institute for Marine Remote Sensing (IMaRS), University of South Florida (USF) for critical assistance in acquisition of remote sensing data.

\section{Conflict of Interest}

The authors declare that they have no conflicts of interest.

\section{References}

[1] Lieske E, Fiedler KE, Myers RF. Coral Reef Guide: Red Sea to Gulf of Aden, South Oman; [the Definitive Guide to Over 1200 Species of Underwater Life]: Collins; 2004.

[2] Ahmed B. Cost of Degradation of Coral reefs and Fisheries Caused by Tourism Development, Egypt's Red Sea A case study of Hurghada-Safaga Area. Institute of National Planning, Cairo, Nasr City, Egypt. http://kenanaonline. com/users/drBarrania/posts/119025. 2010.

[3] Spalding M, Spalding MD, Ravilious C, Green EP. World atlas of coral reefs: Univ of California Press; 2001.

[4] PERSGA. The status of Coral Reefs in the Red Sea and Gulf of Aden: 2009: PERSGA, technical series no 16, PERSGA Jeddah. 2010.

[5] Kotb MM, Hanafy MH, Rirache H, et al. Status of coral reefs in the Red Sea and Gulf of Aden region. Status of coral reefs of the world. 2008:67-78.

[6] Shaalan IM. Sustainable tourism development in the Red Sea of Egypt threats and opportunities. Journal of Cleaner Production. 2005; 13(2):83-87.

[7] Smits R, Shousha N. Egypt's Red Sea resorts... trends and opportunities'. Hotel on Lone. 1998.

[8] Holden A. Environment and Tourism. 2000.

[9] Hilmi N, Safa A, Reynaud S. Coral Reefs and Tourism in Egypt's Red Sea. Topics in Middle Eastern and North African Economies. 2012; 14.

[10] Serour RK. An environmental economic assessment of the impacts of recreational scuba diving on coral reef systems in Hurghada, the Red Sea, Egypt2004.

[11] Hawkins JP, Roberts CM. The growth of coastal tourism in the Red Sea: present and future effects on coral reefs. Ambio. 1994; 23(8):503-508.
[12] GEF. Report 4 - Reef Recreation Management Action Plan for the Egyptian Red Sea 1998.

[13] Bryant D, Burke L, McManus J, Spalding M. Reefs at risk: a map-based indicator of threats to the worlds coral reefs. 1998.

[14] Wilson EH, Hurd JD, Civco DL, Prisloe MP, Arnold C. Development of a geospatial model to quantify, describe and map urban growth. Remote sensing of environment. 2003; 86(3):275-285.

[15] Mundia CN, Aniya M. Analysis of land use/cover changes and urban expansion of Nairobi city using remote sensing and GIS. International journal of Remote sensing. 2005; 26(13):2831-2849.

[16] Shalaby A, Tateishi R. Remote sensing and GIS for mapping and monitoring land cover and land-use changes in the Northwestern coastal zone of Egypt. Applied Geography. 2007; 27(1):28-41.

[17] Haïfa Ben-Romdhane, Mohamed Al-Musallami, Prashanth Reddy Marpu, Taha B. M. J. Ouarda \& Hosni Ghedira (2018): Change detection using remote sensing in a reef environment of the UAE during the extreme event of El Niño 2015-2016, International Journal of Remote Sensing, DOI: $10.1080 / 01431161.2018 .1460502$.

[18] J. D. Hedley, Chris Roelfsema, Vittorio Brando, Claudia Giardino, Tiit Kutser, Stuart Phinn, Peter J. Mumby, Omar Barrilero, Jean Laporte, Benjamin Koetz (2018): Coral reef applications of Sentinel-2: Coverage, characteristics, bathymetry and benthic mapping with comparison to Landsat 8. Remote Sensing of Environment 216 (2018) 598-614.

[19] Alberti M, Weeks R, Coe S. Urban land-cover change analysis in central Puget Sound. Photogrammetric Engineering \& Remote Sensing. 2004; 70(9):1043-1052.

[20] Xiao J, Shen Y, Ge J, et al. Evaluating urban expansion and land use change in Shijiazhuang, China, by using GIS and remote sensing. Landscape and urban planning. 2006; 75(12):69-80.

[21] Batty M, Howes D. Predicting temporal patterns in urban development from remote imagery. 2001.

[22] Herold M, Goldstein NC, Clarke KC. The spatiotemporal form of urban growth: measurement, analysis and modeling. Remote sensing of Environment. 2003; 86(3):286-302.

[23] E. E. Ampoua, Sylvain Ouillon, Corina Iovan, Serge Andréfouët (2018): Change detection of Bunaken Island coral reefs using 15 years of very high resolution satellite images: A kaleidoscope of habitat trajectories. Marine Pollution Bulletin 131 (2018) 83-95.

[24] Muller D, Zeller M. Land use dynamics in the central highlands of Vietnam: a spatial model combining village survey data with satellite imagery interpretation. Agricultural Economics. 2002; 27(3):333-354.

[25] Macleod RD, Congalton RG. A quantitative comparison of change-detection algorithms for monitoring eelgrass from remotely sensed data. Photogrammetric engineering and remote sensing. 1998; 64(3):207-216.

[26] Singh A. Review article digital change detection techniques using remotely-sensed data. International journal of remote sensing. 1989; 10(6):989-1003. 
[27] Zainal A, Dalby D, Robinson I. Monitoring marine ecological changes on the east coast of Bahrain with Landsat TM. Photogrammetric Engineering and Remote Sensing;(United States). 1993; 59(3).

[28] Ahmad W, Neil DT. An evaluation of Landsat Thematic Mapper (TM) digital data for discriminating coral reef zonation: Heron Reef (GBR). International Journal of Remote Sensing. 1994; 15(13):2583-2597.

[29] EEAA. annual reports on impact monitoring program at the Red Sea, Gulf of Suez and Gulf of Aquba. Egyptian Environmental Affairs Agency unpublished reports. . 19982012.

[30] Lyzenga DR. Remote sensing of bottom reflectance and water attenuation parameters in shallow water using aircraft and Landsat data. International journal of remote sensing. 1981; 2(1):71-82.

[31] Q. T. K. Ngoc (2018): Assessing the value of coral reefs in the face of climate change: The evidence from Nha Trang Bay, Vietnam . Ecosystem Services 35 (2019) 99-108.

[32] Bank W. Arab Republic of Egypt, Cost Assessment of Environment Degradation Report, Rural Development. Water and Environment Dep. Middle East and North Africa Region. 2002 .

[33] Vanderstraete T, Goossens R, Ghabour T. The use of multi temporal Landsat images for the change detection of the coastal zone near Hurghada, Egypt. International Journal of Remote Sensing. 2006; 27(17):3645-3655.

[34] El-Gamily H, Nasr S, El-Raey M. An assessment of natural and human-induced changes along Hurghada and Ras Abu Soma coastal area, Red Sea, Egypt. International Journal of Remote Sensing. 2001; 22(15):2999-3014.

[35] Kamh S, Ashmawy M, Kilias A, Christaras B. Evaluating urban land cover change in the Hurghada area, Egypt, by using GIS and remote sensing. International Journal of Remote Sensing. 2012; 33(1):41-68.
[36] Dewidar KM. Landfill detection in Hurghada, North Red Sea, Egypt, using thematic mapper images. International Journal of Remote Sensing. 2002; 23(5):939-948.

[37] Moufaddal WM. Use of satellite imagery as environmental impact assessment tool: a case study from the NW Egyptian Red Sea coastal zone. Environmental Monitoring and Assessment. 2005; 107(1-3):427-452.

[38] Reopanichkul P, Schlacher TA, Carter R, Worachananant S. Sewage impacts coral reefs at multiple levels of ecological organization. Marine Pollution Bulletin. 2009; 58(9):13561362.

[39] Baker D, Rodriguez-Martinez R, Fogel M. Tourism's nitrogen footprint on a Mesoamerican coral reef. Coral Reefs. 2013; 32(3):691-699.

[40] Naumann MS, Bednarz VN, Ferse SC, Niggl W, Wild C. Monitoring of coastal coral reefs near Dahab (Gulf of Aqaba, Red Sea) indicates local eutrophication as potential cause for change in benthic communities. Environmental monitoring and assessment. 2015; 187(2):44.

[41] Wilson M, de Meyer K, Skeat H. The GEF Egyptian Red Sea Coastal and Marine Resource Management Project. A decade of effort, experience and trade-offs required to achieve marine tourism and conservation goals. presented at: First International Tropical Marine Ecosystems Management Symposium (ITMEMS)1998.

[42] Jameson SC, Ammar M, Saadalla E, Mostafa H, Riegl B. A coral damage index and its application to diving sites in the Egyptian Red Sea. Coral reefs. 1999; 18(4):333-339.

[43] Riegl B, Luke K. Ecological parameters of dynamited reefs in the northern Red Sea and their relevance to reef rehabilitation. Marine Pollution Bulletin. 1999; 37(8-12):488-498.

[44] JICA aE. State of oil pollution and management in Suez Gulf region. Japan International Cooperation Agency and Egyptian Environmental Affairs Agency. No. 135-139. 2008. 